\title{
Critical Success Factors on PPP Water Project in a Developing Country: Evidence from Indonesia
}

\author{
Eko Nur SURACHMAN ${ }^{1}$, Dian HANDAYANI ${ }^{2}$, Maman SUHENDRA ${ }^{3}$, Sakti PRABOWO ${ }^{4}$
}

Received: August 01, 2020 Revised: September 06, 2020 Accepted: September 10, 2020

\begin{abstract}
This study aims to explore the critical success factors of the Water Public-Private Partnership (PPP) Projects in developing country with evidence from Indonesia. We all know that water is a basic need and therefore it becomes very important for the governments especially in the developing countries to develop and formulate a comprehensive water policy to deliver and manage the water services in the most appropriate manner as well tackle several challenges such as budget and project efficiency. In this context, PPP is a promising scheme to address the water problems, hence it becomes important to reveal the success factors of water PPP projects. An Analytic Hierarchy Process (AHP) questionnaire built from delphi methods is used to capture the perception of the relevant stakeholders in relation to the success factors. The results of this study show the most critical success factors in PPP water projects is the support and acceptance of the stakeholders from the community, whereas the private and public entities are the the second and third important factors . These findings contribute to the success of the PPP stakeholders by enhancing the policy-making decision process and by executing the water policies to support the development of PPP in the Water Sector.
\end{abstract}

Keywords: Critical Success Factors, Public-Private Partnership, Water Infrastructure Project, Water Management

JEL Classification Code: H44, H54, Q58, O18

\section{Introduction}

"Water is life," as quoted from Secretary-General of United Nations (2018). Almost all objectives of Sustainable Development Goals (SDGs) namely, zero hunger, good health and well-being, sustainable cities and communities, responsible consumption and production, climate action,

${ }^{1}$ First Author and Corresponding Author. Lecturer, Accounting Department, Polytechnic State Finance - STAN (PKN STAN), Indonesia [Postal Address: JI Bintaro Utama III, Pondok Aren, Tangerang Selatan, Banten, 15222, Indonesia]

Email: e.nursurachman@pknstan.ac.id

'Lecturer, Accounting Department, Polytechnic State Finance STAN (PKN STAN), Indonesia. Email: dihandayani@gmail.com ${ }^{3}$ Lecturer, Accounting Department, Polytechnic State Finance STAN (PKN STAN), Indonesia. Email: msuhendra@gmail.com ${ }^{4}$ Lecturer, Accounting Department, Polytechnic State Finance STAN (PKN STAN), Indonesia. Email: bowo.saktie@gmail.com

(c) Copyright: The Author(s)

This is an Open Access article distributed under the terms of the Creative Commons Attribution Non-Commercial License (https://creativecommons.org/licenses/by-nc/4.0/) which permits unrestricted non-commercial use, distribution, and reproduction in any medium, provided the original work is properly cited. marine life, and life on land are related to the availability and sustainable management of water. Thus, adequate water supply capacity and integrated water resources management are important indicators in the achivement of these objectives (BPS, 2018). Failing to achieve this SDG objective number 6 (SDG 6) will hamper the progress on all other SDGs. Nevertheless, providing accessible water resources and safe drinking water is fundamental and directly linked to improving social well-being and economic productivity. The next more important step after setting the objectives si to enable and accelerate the activities to achieve these objectives. The challenging issues faced by the water sector is to improve water resources management and to increase the coverage and quality of water and sanitation services. Synthesis report of the United Nations (2018) emphasizes that there are four interlinked critical elements in achieving SDG 6, which are governance, finance, capacity development, data acquisition and monitoring. Effective policies in each of these activities are mutually reinforcing.

While good water governance is an essential support for implementing SDG 6, nevertheless governance structures in many countries tend to be weak and disintegrated. Many 
government responsibilities require governance functions, such as formulating policy, developing legal frameworks, planning, coordination, funding and financing, capacity development, data acquisition and monitoring, and regulation. One way to overcome the issues without overwhelming the governance functions is to take into account the engagement with other stakeholders, including the local government and private sector, and the Public-Private Partnership scheme is promoted to achieve those seventeen SDGs (Cui, Liu, Hope, \& Wang, 2018).

According to the Indonesian government, in 2018, the coverage of water supply in Indonesia reached about $72 \%$ (Public Relations, 2018). The government also pointed out that water supply management in Indonesia has to be managed by Water Local State-Owned Enterprises even though their performance report for 2017 showed that only $55,3 \%$ companies had an excellent performance, which comes to be a total of 209 out of 378 companies. This condition makes the level of services delivered to the customers of very poor quality. Furthermore, privatization in water supply management has become a problem not only in the business model but also in the institutional arrangement of the project (Jensen, 2005), causing the cancellation of the 2004 Water Resources Law in February 2015. The water management problem also led to civil claims between local government and the private sector as seen in Jakarta, the capital of Indonesia, the issues still remain unresoved. Statement by the law and privatization problem then only leaves the government with two options in building and managing water infrastructure by state budget or PPP scheme.

In another perspective, government should focus on public expenditure and investment for the low and middle class economic households, as their contribution is significant in the economic growth (Salim, Rustam, Haeruddin, \& Asriati, 2020). It means that the involvement of the private sector is inevitable to maximise the development. While the debate is still going on about the lack of state budget that hinders the government from providing acceptable water level services as an essential need for the society, the efficiency and proper use of funds related to the infrastructure are some of the primary issues faced by the government. Under the new public management concept, the government is facing inefficiency problems, not only in the bureaucratic process but also in the goods and services procurement. The government monopolizes the infrastructure development and its operation while they often have no incentive to boost efficiency through its structure and business processes (Zhang, Gao, Feng, \& Sun, 2015). On the other hand, the private sector has the promary goal and objective to generate cash flow and profitability. This goal is generally achieved through investment and operation efficiency (Felsinger, Miranda, Skilling, \& Booth, 2008).
Governments turn to the Public-Private Partnership (PPP) in order to introduce new technology and innovation where traditional sources are being threatened (Unicef, 2016). The PPP is seen as an opportunity to solve inefficiency problems (APMG, 2017; Liu, Wang, \& Wilkinson, 2016), and also to cope with the limited resources through competition, the economy of scale, and project finance (Rakić \& Rađenović, 2011). Increase in efficiency is expected to come through various arrangements in a well-structured and wellmanaged project which emphasizes on several factors such as cost management, life cycle management, reliability and effectiveness, innovation, risk management, and utilization (APMG, 2017). PPP becomes a strategy to pursue value for money as a merit by utilizing synergic cooperation among private and public (Cui et al., 2018; Zhang et al., 2015). Moreover, PPP also promotes financing source diversification from the private sector point of view. They are looking for business opportunities to seek for better returns (Lee, 2020). These approaches encourage the use of a public-private partnership scheme to provide infrastructure facilities. Public-private partnerships (PPPs) scheme is being increasingly used by many developing countries to provide civic facilities. PPP is best described as a partnership between the public and private sector where risk and responsibilities are shared between both the parties. This is further defined as optimal risk allocation as per the ability of a concern to handle and mitigate the risk factors in question.(Osei-Kyei \& Chan, 2018).

PPP scheme saw growing interest in the late 1990s (Osei-Kyei \& Chan, 2015) and since then many developed and developing countries are using it. During years of PPP implementation, several studies have analyzed the critical success factors (CSFs) of PPP projects. These studies share the experienecs and the lesson learnt in any secific PPP project so that the next project learns and improves from it though it is apparent that each of the PPP projects are unique and different because of different conditions in different countries Osei-Kyei \& Chan (2015) explored and revealed that the five most reported CSFs in the period of 1990 to 2013 is risk allocation and sharing, a robust private consortium, political support, community/public support, and transparent procurement. Most of those findings have been incorporated into government guidelines to be used by local practitioners on the best ways to manage and deliver PPP projects. Later on, it was found that there has been a gradual shift in research interest by identifying countryspecific PPP CSFs to best international practices, while other projects focus on their own regional and country specific uniqueness in implementing PPP projects (Chaponda et al., 2014; Mudi et al., 2016).

Indonesia is one of the developing countries that has used PPP as a scheme to provide water infrastructure. Since 2005, 
a lot of efforts have been taken to utilize and develop PPP in the water sector. It is admitted as the best solution to answer the need to build water infrastructure without involving state or local government finances (Putra, 2018). Since then, three water projects have been successfully delivered using this scheme, namely Water Project Umbulan-East Java, Semarang Barat-Central Java, and Bandar LampungLampung Sumatera. This achievement attracts many more water projects to adopt the PPP in order to provide water services to the society. Therefore, it is interesting to capture the critical success factors of the projects so that they can be applied to the other projects.

\section{Literature Review}

Common conclusions from previous research agreed that water projects have high priority but contain very complex risks. The complexity of the water project has been identified by Ameyaw \& Chan (2015), where they have mentioned 11 critical factors which can have a great impact on the value, these are: contract design; uncertainty in service prices and review of service rates; political interference; public rejection of PPP schemes; construction period and cost overrun; non-payment of bills; lack of experience in running PPP schemes; financing and refinancing risks; faulty demand forecasting (over-estimation); high operational costs; and conflicts between partners. However, further research on the eleven risks shows that the value of those risks must be treated according to the context of the specific country in which the PPP project was implemented, as well as the project's efficient implementation to ensure the success of private participation in water procurement services. The risk mitigation becomes crucial because drinking water commodity cannot be seen merely as a commercial product, but it should also take into account broader aspects such as politics, socio-cultural, technological, environmental and legislative issues (Prasad, 2007).

Furthermore, Ameyaw \& Chan (2016) also revealed that PPP projects in the sector of providing water services, especially in developing countries, would be optimal if there was a risk-sharing between the government and the private sector. Appropriate risk allocation for each party will increase the effectiveness of risk management and will have a positive impact on the smooth running of the project. The principle of risk allocation is also an essential part of the critical factors determining the success of PPP projects, as mentioned by Osei-Kyei \& Chan (2015), in addition to a robust private consortium, political support, public support, and a transparent procurement process.

A study in Indonesia carried out by Wibowo \& Mohamed (2010) uncovers a severe problem faced by the government in the provision of water supply. Local operators known as
PDAMs (Perusahaan Daerah Air Minum) are expected to operate as profit-making enterprises despite being owned by the public sector. It was discovered that about $90 \%$ of PDAMs are in unhealthy financial condition and barely sustain without the government's financial support. Problems arise in the technical side where PDAMs are facing low water availability as well as quality. Government restructuring program for PDAMs is aimed at helping PDAMs to operate in a more competitive way similar to that of the private sector, thus they stop depending on government support. PPP scheme came in the picture since the fundamental concept of PPP is about risk-sharing. The private sector is likely to bear the risks that are familiar to them, such as development, construction, commissioning, and operating risks. In comparison, the public sector will take all the uncontrollable risks like political, country commercial, indeterminate demand risks, and uninsurable force majeure risks (Wibowo $\&$ Mohamed, 2010). By studying the allocation of the risk in water supply, it will help the government to minimize uncertainty and consumer loss.

Other than risk, another important factor is the role of the government, especially in providing flexibility in the procurement process. According to Cheung et al. (2012) the role of the government is mainly to listen to the private proposals and provide certainty in the event of contract implementation problems (default) They also highlighted the influence of host country experience on the success rate of PPP projects in a country. For countries that have experience in implementing PPP, the factors that influence the success of PPP projects are government competence, appropriate concessions, appropriate risk allocation between the government and the private sector, and the sound financial package. But for countries that are just beginning to try PPP financing schemes, social stability and political support are crucial.

In the case of a health PPP project implementation in Kazakhstan, the government realized that each PPP project was unique and as a consequence it needed different treatment both in terms of selection process and regulatory approach (Yessentay, Kireyeva, Khalitova, \& Abilkayir, 2020). As the need for more significant private sector's participation in infrastructure development in many countries is in demand, then the governments should invite a variety of relevant parties who can finance the costs of building the water infrastructure as well as create an appropriate finance mechanisms to different infrastructure asset classes (Lee, 2020). Moreover, the understanding of sources of conflict in Vietnam can accelerate the construction progress in the country as it can give an idea as what is required to succesfully implement the infrastructure projects and how to achive an improved risk mitigation of related parties (Vo, Nguyen, Le, Thuy, \& Nguyen, 2020). 
A real example is discussed in the study where the failure of PPP projects that occurred in Bangkok was caused by a change of government as the new government cancelled the PPP project which often happens with the shange in government in many countries (Cheung et al., 2012). The essence of the whole study is that the government must focus on the timeliness and quality of the project results according to agreed criteria. Another study from Putra (2018) pointed out that the PPP water projects are able to reach the final procurement stage because there is some support from the national government, namely: viability gap fund facility, networking distribution support facility, and risk allocation, among others. Furthermore, the water sector PPP in Indonesia is explored by Purbo, Smith, \& Bianchi (2019) which revealed that the goal of the central government and sub-national government to utilize PPP as a scheme to provide the water infrastructure are different. The differences include the Role of Local Leaders, the understanding of Value for Money as well as Effectiveness and Efficiency Value, and the benefit to adopt PPP to the local economic development. At the same time, both of the government levels agreed that the biggest obstacle to the development of PPP in the water sector is the vertical coordination of the PPP projects.

Research conducted by Shi et al (2016) on the case study of four water service procurement projects in China with the Transfer-Operate-Transfer scheme, showed that there are eight critical success factors in water projects including (1) project profitability, (2) asset quality, (3) fair risk allocation, (4) competitive procurement processes, (5) coordination internal with the government, (6) professional advisors, (7) corporate governance, and (8) government supervision. The identification of these eight factors can be grouped into four categories of critical success factors, namely public sector-related factors, private sector-related sectors, environment-related factors, and services provision process.

More specifically, a work by Ameyaw et al. (2017) has ranked $17 \mathrm{CSFs}$ as significant or very significant, which indicates that the list has got a lot of relebance for private sector's investment decision. Among the top-eight CSFs are (1) political commitment from the elected government toward PPPs for water supply, (2) existence of dedicated PPP unit, (3) reliable and competent public water authority, (4) adequate fiscal capacity of the national/subnational authority, (5) public acceptance and support of the involvement of private sector in water services, (6) a well-designed PPP contract, (7) existence of enabling policy and legal frameworks to support water PPPs, and (8) profitability of water project(s) to attract investors. The list consists of what the private sector takes into consideration before participating in water PPPs. Thus it can be valuable for the governments to support their PPP programs.

\section{Research Methods and Materials}

In order to capture the perception of the PPP stakeholders about the critical success factors of the water PPP Project, a questionnaire is deployed. The questionnaire built is based on a critical literature review using content analysis from various journals and references. The result is then scrutinized and adjusted in the context of PPP in Indonesia using Delphi Technique. The questionnaire is distributed to the research respondents, both from the public side and the private side. The respondent includes Government Contracting Agencies (the project owner) and the PPP private company. Moreover, the study also involves other PPP stakeholders, namely the Ministry of Finance, Ministry of Economic Affairs coordination, Multilateral agencies (World Bank and G-20 Infrastructure Desk), Project Guarantor, Project Lenders, as well as PPP consultants and experts who involve in the PPP project preparation.

The data from questionnaires taken from respondents is processed with an Analytic Hierarchy Process (AHP) to get systematic structure from several articulated factors to determine the importance levels of the factors. This analytic decision model helps to prioritize several alternatives or criteria. AHP also has a measurement scale for consistency in intangible and qualitative data, and improving the judgment quality of the derived factors from the questionnaire (Brunelli, 2015; Saaty, 2008). It relies on the judgments of experts to make the prioritization precisely (Saaty, 2008). AHP helps to establish consistency and clarity in weighing several critical success factors from many observers (Latorre \& Riley, 2010). AHP with qualitative fuzzy logic questionaire is also a robust way to reveal critical success factors of a phenomena (Nguyen, Le, Thuy, \& Nguyen, 2020). In this context, critical success factors in PPP are mostly qualitative data and which involves judgement from each observer. Those factors are perceived based on the observer's practical experience and standpoints. However, AHP as a form of mathematical science could offer a measurement of intangible criteria that serves as a guide to rank and decide the critical activities that are favorable to the project's outcome (Latorre \& Riley, 2010; Saaty, 2008)

In AHP, the pairwise comparison becomes an effective method to compare various alternatives at the same time so that it can overcome cognitive limitations in decision making. This method will decompose criteria into various levels ranging from objectives, factors, criteria, sub-criteria, and attributes. This hierarchy provides a structured and systematic manner in selection of the factors. Given a pairwise comparison, Chen (2006) points out that the analysis consists of three steps, namely (1) developing a comparison matrix at each level of the hierarchy starting from the second level and working down, (2) computing the relative weights for each element of the hierarchy, and (3) estimating the consistency ratio to check the consistency of the judgment. 
Eko Nur SURACHMAN, Dian HANDAYANI, Maman SUHENDRA, Sakti PRABOWO I

Table 1: Random Consistency Index (RI)

\begin{tabular}{|l|c|c|c|c|c|c|c|c|c|c|}
\hline $\mathbf{N}$ & $\mathbf{1}$ & $\mathbf{2}$ & $\mathbf{3}$ & $\mathbf{4}$ & $\mathbf{5}$ & $\mathbf{6}$ & $\mathbf{7}$ & $\mathbf{8}$ & $\mathbf{9}$ & $\mathbf{1 0}$ \\
\hline $\mathrm{RI}$ & 0,00 & 0,00 & 0,58 & 0,90 & 1,12 & 1,24 & 1,32 & 1,41 & 1,45 & 1,49 \\
\hline
\end{tabular}

The questionnaire used in this study has outlined the objectives in 3 levels. In the Criteria Level (Level 1), there are four criterias, The Sub Criteria (Level 2), there are 12 components, and the Attributes (Level 3) that describe those two levels above consist of 37 attributes. The comparison matrix calculation is then carried out and continued by normalizing the Eigenvector of the matrix. The normalization is done to calculate the priority vector estimation, which shows the relative weights of the various alternatives compared. The normalization is done using the geometric mean method according to the following equation.

$$
a_{i}=\left(\prod_{j=i}^{n} a_{i j k}\right)^{\frac{1}{n}}
$$

$a_{i}$ is the relative importance of attribute $\mathrm{i}$ to attribute $\mathrm{j}$, $\mathrm{n}=$ number of respondents, $\alpha_{i j k}$ is the relative importance of attribute $\mathrm{i}$ to attribute $\mathrm{j}$ by respondent $\mathrm{k}$. The following equation then determines the weight.

$$
\text { Anxn wnx } 1=\lambda \max w n x
$$

with $\mathrm{A}=$ paired comparison matrix that has an element of $\alpha_{i j}$, $\mathrm{w}=$ matrix-vector of weight estimation, and $\lambda \max =$ largest Eigenvalue.

Because the model of decision making is related to human judgment, consistency is relative and unmeasured in absolute terms. The Comparison matrix is considered consistent if the largest Eigenvalue is equal to the number of comparisons. The measure of consistency is then measured by the Consistency Index (CI), compared with the Random Consistency Index (RI) to obtain a Consistency Ratio where the equation calculates CI:

$$
C I=\frac{\lambda \max -\mathrm{n}}{n-1}
$$

then, $\mathrm{CR}$ is calculated by the equation:

$$
C R=\frac{C I}{R I}
$$

The value of RI has been determined by Saaty as follows:

Furthermore, the aggregate consistency ratio $\left(\mathrm{CR}_{\text {agg }}\right)$ is calculated because the calculation of the consistency ratio (CR) previously still calculates individually. Equation 5 can be used to calculate $\mathrm{CR}_{\text {agg }}$

$$
\mathrm{CR}_{\mathrm{agg}}=\frac{\prod_{i=1}^{t} w i C I i}{\prod_{i=1}^{t} w i R I i}
$$

$\mathrm{CR}_{\text {agg }}$ is an aggregate consistency ratio and $\mathrm{t}$ is the number of reciprocal matrices evaluated for the level of consistency. A matrix is consistent if the $\mathrm{CR}$ value is less than $10 \%$ (CR $<10 \%$ ).

\section{Results and Discussion}

Based on the literature review above, there is a threelevel of success factors. The first level (criteria) is the macro factor followed by more detail factor in the sub-criteria level and attributes level.

\subsection{Level 1 (Criteria) Result}

All of the respondents participated in the research by filling the AHP questionnaire. According to Chen (2006), the next step is to compute the relative weights for each element of the hierarchy. The calculation for each Level 1 and 2 results in a local ranking, and the weight of all Attributes at Level 3 results in a global ranking. At Level 1 the weighting results show "Conducive Stakeholder Support" as the most important criterion (48\%), the rest is allocated to "Proportional Risk Allocation and Adequate Regulatory Support" (25\%), "The Process of Preparing a Comprehensive Feasibility Study" (19\%) and in the last rank "Precondition for thorough Project Preparation" (8\%).

The result shows that in the water sector, the support from the stakeholders is much more critical compared to the technical aspects such as risk allocation, regulatory basis, and comprehensive feasibility study and project preparation. It should give insight to the government to take into account and prioritize the perception of the stakeholders from the beginning of project preparation.

\subsection{Level 2 (Sub-Criteria) Result}

The highest weight Level 2 in the first rank criteria, "Conducive Stakeholder Support," was "Community Readiness" $(50 \%)$. It is followed by the "Private Sector Readiness" (31\%) and "Public Sector Readiness" (19\%). The detail of the statistical result is seen in Table 2. It can be seen from the table that CR is less than $0.1(0.09,0.03$, and 0.06 , respectively), which means that the level of consistency of the results of the AHP questionnaire is reliable. The conclusion points out that, among several stakeholders, the support of society is very critical. It includes the prospective users and the people around the project site that get an impact from the project (see Table 2). 


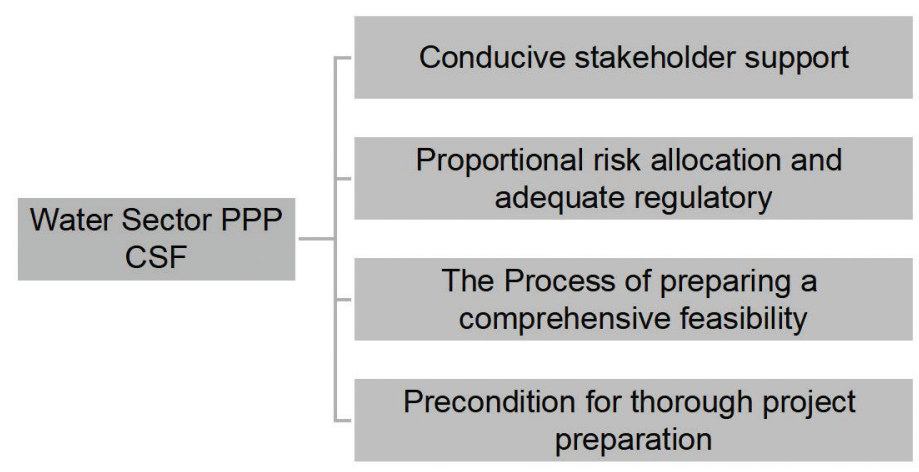

Figure 1: Criteria of Water Sector PPP Critical Success Factors

Table 2: Local and Global AHP Ranking for Criteria Conducive Stakeholder Support

\begin{tabular}{|c|c|c|c|c|}
\hline \multirow{2}{*}{$\begin{array}{l}\text { Sub Criteria } \\
\text { (Weight) }\end{array}$} & \multirow{2}{*}{ (Local Rank) (Local Weight) Attribute } & \multicolumn{3}{|c|}{ Consistency Measures } \\
\hline & & $\mathrm{Cl}$ & RI & CR \\
\hline \multirow{3}{*}{$\begin{array}{l}\text { Community } \\
\text { Readiness } \\
(50 \%)\end{array}$} & (1) $(53 \%)$ Overall public acceptance of the project & \multirow{3}{*}{0.05} & \multirow{3}{*}{0.58} & \multirow{3}{*}{0.09} \\
\hline & (2) (34\%) Encouraging and facilitating the participation of affected communities & & & \\
\hline & $\begin{array}{l}\text { (3) }(13 \%) \text { Optimizing public communication regarding the transparency } \\
\text { principle of conducting the business auction }\end{array}$ & & & \\
\hline \multirow{3}{*}{$\begin{array}{l}\text { Private Sector } \\
\text { Readiness } \\
(31 \%)\end{array}$} & (1) $(63 \%)$ Investor understanding of the cooperated infrastructure sector & \multirow{3}{*}{0.02} & \multirow{3}{*}{0.58} & \multirow{3}{*}{0.03} \\
\hline & (2) $(23 \%)$ Having competitive industrial and domestic labor support & & & \\
\hline & (3) (14\%) Having long-term local financing support/access & & & \\
\hline \multirow{4}{*}{$\begin{array}{l}\text { Public Sector } \\
\text { Readiness } \\
(19 \%)\end{array}$} & $\begin{array}{l}\text { (1) }(44 \%) \text { Projects with a national scope need to be supported by innovative } \\
\text { auction assessments }\end{array}$ & \multirow{4}{*}{0.06} & \multirow{4}{*}{0.90} & \multirow{4}{*}{0.06} \\
\hline & (2) $(26 \%)$ Placing PPP as an option in providing infrastructure & & & \\
\hline & (3) $(20 \%)$ Increasing the capacity of individuals and institutions related to PPP & & & \\
\hline & (4) $(11 \%)$ Having a robust legal framework & & & \\
\hline
\end{tabular}

Furthermore, in the second-ranking criteria, "Proportional risk allocation and adequate regulatory support," the highest weight is in the sub-criteria "Government policy to ensure contracts are met" (51\%). The rest is spread in the subcriteria "Adaptive risk management for change" (33\%) and "Attractive and mutually beneficial cooperation contracts" $(16 \%)$. Details of the results of the statistics can be seen in Table 3. From each Sub Criteria in the Criteria, CR is respectively $0.08,0.15$, and 0.17 . Even though there are Sub Criteria that have CR more than 0.1, but according to Saaty, it is sometimes acceptable. Researchers can doubt the consistency of AHP results if the CR is very high to reach 0.9. If that happens, according to Saaty, the AHP results are not reliable (see Table 3).

Moreover, in the third rank namely "The process of preparing a comprehensive feasibility study," the highestranking in this criteria is "Supporting preconditions, namely stakeholder involvement, legal basis, licensing and land acquisition" (52\%), followed by "Financial Feasibility" $(30 \%)$ and "Technical scope that makes sense" $(18 \%)$. The results of the statistics ranked third in this Criteria can be seen in Table 4. From each Sub Criteria in the Criteria, CR is $0.05,0.13$, and $0.1,4$, respectively. Moreover, moving to the process of building a feasibility study, it is essential to prepare for the precondition factors before starting to compose the feasibility study such as the land acquisition plan, as well as permit and the legal basis (see Table 4).

Lastly, the fourth rank criterion is "Precondition for thorough project preparation." The highest-ranking in this sub-criteria is "Adequate project preparation funding" $(56 \%)$, then "Project management with clear governance" $(30 \%)$ and "Cross-sector team with solid leadership " $(14 \%)$, as can be seen in Table 5. From each Sub Criteria in the Criteria, CR, respectively $0.04,0.07$, and 0.09 . As previously explained, even though there are Sub Criteria that have a CR of more than 0.1, but according to Saaty, this is sometimes acceptable. In these criteria, when the government starts to implement project preparation, it is crucial to make sure that there are sufficient funds to finance the project preparation (see Table 5). 
Table 3: Local and Global AHP Ranking for Proportional Risk Allocation and Adequate Regulatory Support

\begin{tabular}{|c|c|c|c|c|}
\hline \multirow{2}{*}{$\begin{array}{l}\text { Sub Criteria } \\
\text { (Weight) }\end{array}$} & \multirow{2}{*}{ (Local Rank) (Local Weight) Attributes } & \multicolumn{3}{|c|}{$\begin{array}{l}\text { Consistency } \\
\text { Measures }\end{array}$} \\
\hline & & $\mathrm{Cl}$ & RI & CR \\
\hline \multirow{3}{*}{$\begin{array}{l}\text { Government policy } \\
\text { to ensure contracts } \\
\text { are met }(51 \%)\end{array}$} & $\begin{array}{l}\text { (1) }(66 \%) \text { Implement regulations that guarantee the fulfillment of } \\
\text { government commitment to the project }\end{array}$ & \multirow[t]{3}{*}{0.05} & \multirow[t]{3}{*}{0.58} & \multirow[t]{3}{*}{0.08} \\
\hline & $\begin{array}{l}\text { (2) }(20 \%) \text { Providing space for the government to conduct measurable and } \\
\text { reasonable interventions }\end{array}$ & & & \\
\hline & $\begin{array}{l}\text { (3) }(14 \%) \text { Implement adequate regulations with efficient monitoring to } \\
\text { ensure contracts are fulfilled }\end{array}$ & & & \\
\hline \multirow{3}{*}{$\begin{array}{l}\text { Adaptive risk } \\
\text { management for } \\
\text { change }(33 \%)\end{array}$} & $\begin{array}{l}\text { (1) }(59 \%) \text { Providing infrastructure risk guarantee facilities through credible } \\
\text { entities }\end{array}$ & \multirow[t]{3}{*}{0.09} & \multirow[t]{3}{*}{0.58} & \multirow[t]{3}{*}{0.15} \\
\hline & (2) $(26 \%)$ Adopt regulations that are adaptive to change & & & \\
\hline & (3) $(15 \%)$ Identify all risks and allocate them to the most appropriate party & & & \\
\hline \multirow{3}{*}{$\begin{array}{l}\text { Attractive and } \\
\text { mutually beneficial } \\
\text { cooperation } \\
\text { contracts }(16 \%)\end{array}$} & $\begin{array}{l}\text { (1) }(56 \%) \text { Regulates the flexibility of transfer of ownership and refinancing in } \\
\text { the contract }\end{array}$ & \multirow[t]{3}{*}{0.10} & \multirow[t]{3}{*}{0.58} & \multirow[t]{3}{*}{0.17} \\
\hline & (2) $(26 \%)$ Implement contracts with revenue incentive arrangements & & & \\
\hline & (3) $(18 \%)$ Adopt a comprehensive contract model in the project cycle & & & \\
\hline
\end{tabular}

Table 4: Local and Global AHP Ranking for The Process of Preparing a Comprehensive Feasibility Study

\begin{tabular}{|c|c|c|c|c|}
\hline \multirow{2}{*}{$\begin{array}{l}\text { Sub Criteria } \\
\text { (Weight) }\end{array}$} & \multirow{2}{*}{ (Local Rank) (Local Weight) Attributes } & \multicolumn{3}{|c|}{$\begin{array}{l}\text { Consistency } \\
\text { Measures }\end{array}$} \\
\hline & & Cl & $\mathbf{R I}$ & CR \\
\hline \multirow{3}{*}{$\begin{array}{l}\text { Supporting } \\
\text { preconditions, } \\
\text { namely stakeholder } \\
\text { involvement, legal } \\
\text { basis, licensing and } \\
\text { land acquisition } \\
(52 \%)\end{array}$} & (1) $(52 \%)$ Provision of adequate government support & \multirow[t]{3}{*}{0.03} & \multirow[t]{3}{*}{0.58} & \multirow[t]{3}{*}{0.05} \\
\hline & $\begin{array}{l}\text { (2) (36\%) Provision of a comprehensive legal basis for the project (including } \\
\text { licensing and land acquisition) }\end{array}$ & & & \\
\hline & (3) (12\%) Stakeholder involvement proactively, inclusive and professionally & & & \\
\hline \multirow[t]{3}{*}{$\begin{array}{l}\text { Financial Feasibility } \\
(30 \%)\end{array}$} & $\begin{array}{l}\text { (1) }(60 \%) \text { Test financial feasibility through early and continuous exploration } \\
\text { of market interest }\end{array}$ & \multirow[t]{3}{*}{0.07} & \multirow[t]{3}{*}{0.58} & \multirow[t]{3}{*}{0.13} \\
\hline & $\begin{array}{l}\text { (2) }(28 \%) \text { Optimizing all direct revenue potential (rates and payments from } \\
\text { the government) }\end{array}$ & & & \\
\hline & $\begin{array}{l}\text { (3) }(12 \%) \text { Identify all potential indirect income (value capture land and area } \\
\text { management) }\end{array}$ & & & \\
\hline \multirow{3}{*}{$\begin{array}{l}\text { The technical } \\
\text { scope that makes } \\
\text { sense }(18 \%)\end{array}$} & $\begin{array}{l}\text { (1) }(59 \%) \text { Availability of analysis of technical options for project } \\
\text { implementation }\end{array}$ & \multirow[t]{3}{*}{0.08} & \multirow[t]{3}{*}{0.58} & \multirow[t]{3}{*}{0.14} \\
\hline & (2) $(26 \%)$ Determine measurable output specifications and by cost projections & & & \\
\hline & (3) $(15 \%)$ Perform accurate user demand projections & & & \\
\hline
\end{tabular}


Table 5: Local and Global AHP Ranking for Precondition For Project Preparation

\begin{tabular}{|c|c|c|c|c|}
\hline \multirow{2}{*}{$\begin{array}{l}\text { Sub Criteria } \\
\text { (Weight) }\end{array}$} & \multirow{2}{*}{ (Local Rank) (Local Weight) Attributes } & \multicolumn{3}{|c|}{ Consistency Measures } \\
\hline & & $\mathrm{Cl}$ & $\mathbf{R} \mathbf{I}$ & CR \\
\hline \multirow{3}{*}{$\begin{array}{l}\text { Adequate project } \\
\text { preparation funding } \\
(56 \%)\end{array}$} & $\begin{array}{l}\text { (1) }(51 \%) \text { Ensuring funding for project preparation from other sources } \\
\text { (donor institutions / international institutions) }\end{array}$ & \multirow[t]{3}{*}{0.02} & \multirow[t]{3}{*}{0.58} & \multirow[t]{3}{*}{0.04} \\
\hline & $\begin{array}{l}\text { (2) }(29 \%) \text { Securing adequate project preparation funding from the } \\
\text { Ministry of Finance (as BUN) }\end{array}$ & & & \\
\hline & $\begin{array}{l}\text { (3) }(20 \%) \text { Ensuring funding of proper project preparation from the } \\
\text { sector (PJPK) }\end{array}$ & & & \\
\hline \multirow{3}{*}{$\begin{array}{l}\text { Project } \\
\text { management with } \\
\text { clear governance } \\
(30 \%)\end{array}$} & $\begin{array}{l}\text { (1) }(53 \%) \text { Prepare a governance structure with details of clear roles } \\
\text { and responsibilities }\end{array}$ & \multirow[t]{3}{*}{0.04} & \multirow[t]{3}{*}{0.58} & \multirow[t]{3}{*}{0.07} \\
\hline & (2) (35\%) Compile careful project management with clear stages & & & \\
\hline & (3) (12\%) Prepare a precise and scheduled coordination model & & & \\
\hline \multirow{3}{*}{$\begin{array}{l}\text { Cross-sector team } \\
\text { with solid leadership } \\
(14 \%)\end{array}$} & (1) (46\%) Establishment of a competent PPP node at the PJPK & \multirow[t]{3}{*}{0.05} & \multirow[t]{3}{*}{0.58} & \multirow[t]{3}{*}{0.09} \\
\hline & $\begin{array}{l}\text { (2) }(38 \%) \text { Get support from the Minister / Head of Institution / Regional } \\
\text { Head }\end{array}$ & & & \\
\hline & (3) $(16 \%)$ Making competent cross-sector teams & & & \\
\hline
\end{tabular}

\subsection{Level 3 (Attributes) Result}

When viewed at Level 3, there are 37 attributes of critical success factors for PDF facilities. According to the global ranking obtained from the results of filling out the AHP questionnaire, the highest-ranking is achieved by the attribute "Overall public acceptance of the project" with a relatively high index of 0.1264 . It is aligned with the level 1 and level 2 result. It is also highlighted that the involvement of the society is an essential factor in the water sector PPP. By involving them from the beginning of the process, the project will gain support and acceptance. Following the public recognition, the attribute "Investor understanding of the cooperated infrastructure sector" is the second important attribute with an index of 0.090 . It gives the perspective that after the public sector, the second party that holds a critical role in the project is the private side.

Furthermore, ranks three and four have an approaching index, namely the attribute "Implement regulations that guarantee the fulfillment of government commitment to the project" $(0.085)$ and encouraging and facilitating the participation of affected people" (0.080). Likewise, ranked the fifth rank, namely "Providing adequate government support" $(0.0499)$. In this area, the role of government is the third most critical success factor in the project.

In light of this, the result of the study is quite impressive. As we may concern, the main party involved in the Public-
Private Partnership project is the Government (Public Side) and PPP Company (Private Side). Yet, the most critical success factor to the project is the involvement and acceptance of the public, either the prospective user or the people surrounding the project site who get impact from the project.

\section{Conclusion}

The results of the study revealed that the external factor from conducive stakeholder support is the key to success for PPP Water projects in Indonesia. First, The stakeholders include all of the society, either the user/customer or the affected communities. It is an interesting fact because they are not the main party in PPP, as we know that traditionally the public (government as the project owner) and the private (PPP Company as the project sponsor) are the ultimate parties in the Public-Private Partnership scheme. Second, the variable relates to government readiness is the next critical success factor. It includes the making of government policy to support the development of PPP by giving the government support and guarantee to the project also by ensuring that all of the regulations are taken care of and are implemented. Third, the success factor is coming from the project packaging itself, including the feasibility of project technicalities, the law and regulation as the basis of the development, and the financial viability of the project. 
Eko Nur SURACHMAN, Dian HANDAYANI, Maman SUHENDRA, Sakti PRABOWO /

Last but not least, the preparation of the project is also crucial to the success factor; here the funding of the project preparation holds the central part of this factor. In order to ensure that the PPP projects are attractive enough to the private sector, the project documentation should be made as comprehensive as possible. It is a big deal for the project owner to do it as they lack required capacities as well as funds. Hence, the government should cover this problem by providing assistance in the form of technical or funding support to build a robust feasibility study.

\section{References}

Ameyaw, E. E., \& Chan, A. P. C. (2016). A Fuzzy Approach for the Allocation of Risks in PPP Water-Infrastructure Projects in Developing Countries. Journal of Infrastructure Systems, 21(December), 395-408. https://doi.org/10.1061/(ASCE)IS

Ameyaw, E. E., Chan, A. P. C., \& Owusu-Manu, D.-G. (2017). A survey of critical success factors for attracting private sector praticipation in water supply projects in developing countries. Journal of Facilities Management, 15. https://doi.org/10.1108/ JFM-07-2016-0030

Ameyaw, E. E., \& Chan, A. P. C. (2015). Risk ranking and analysis in PPP water supply infrastructure projects: An international survey of industry experts. Emerald Insight, 33(7/8), 428-453. https://doi.org/10.1108/F-12-2013-0091

APMG. (2017). Efficiency and Effectiveness: PPP as a Potential Source of Higher Efficiency for Infrastructure Projects. Retrieved March 10, 2020, from: https://ppp-certification.com/ ppp-certification-guide/52-efficiency-and-effectiveness-ppppotential-source-higher-efficiency

BPS. (2018). Indonesia's SDG KPI (1st ed.). Jakarta, Indonesia: Central Agency on Statistic.

Brunelli, M. (2015). Introduction to the Analytic Hierarchy Process (1st ed.). Helsinki: Springer International Publishing.

Chaponda, T., Nikore, M., \& Chennels, M. (2014). Effective Project Preparation for Africa's Infrastructure Development. Retrieved March 15, 2020, from: https://www.icafrica.org/fileadmin/ documents/Publications/Effective_project_preparation_in_ Africa_ICA_Report 31_October_2014.pdf

Chen, C. (2006). Applying the Analytical Hierarchy Process (AHP) Approach to Convention Site Selection. Journal of Travel Research 2006, 45(167). https://doi. org/10.1177/0047287506291593

Cheung, E., Chan, A. P. C., \& Kajewski, S. (2012). Factors contributing to successful public private partnership projects: Comparing Hong Kong with Australia and the United Kingdom. Journal of Facilities Management, 10(February), 45-58. https://doi.org/10.1108/14725961211200397

Cui, C., Liu, Y., Hope, A., \& Wang, J. (2018). Review of studies on the public - private partnerships (PPP) for infrastructure projects. International Journal of Project Management, 1-22. https://doi.org/10.1016/j.ijproman.2018.03.004
Felsinger, K., Miranda, J., Skilling, H., \& Booth, K. (2008). PublicPrivate Partnership Handbook. Retrieved March 12, 2020, from: https://www.adb.org/sites/default/files/institutional-document/ 31484/public-private-partnership.pdf

Jensen, O. (2005). Troubled Partnerships : Problems and Coping Strategies in Jakarta 's Water Concessions. In: Proceeding of 4th Conference on Applied Infrastructure Research (pp. 1-43). October 8, Berlin University of Technology, Berlin, Germany.

Latorre, V., \& Riley, M. (2010). Utilizing analytical hierarchy process to prioritize critical success factors in construction projects. In: Proceedings of 26th Annual ARCOM Conference (pp. 1179-1187). September, Leeds, UK: Association of Researchers in Construction Management, ARCOM.

Lee, J. W. (2020). Green Finance and Sustainable Development Goals: The Case of China. Journal of Asian Finance, Economics and Business, 7(7), 577-586. https://doi.org/10.13106/ jafeb.2020.vol7.no7.577

Liu, T., Wang, Y., \& Wilkinson, S. (2016). Identifying critical factors affecting the effectiveness and efficiency of tendering processes in Public - Private Partnerships (PPPs): A comparative analysis of Australia and China. International Journal of Project Management, 34(4), 701-716. https://doi. org/10.1016/j.ijproman.2016.01.004

Mudi, A., Kolawole, O. B., Yusuf, T. H., \& Ma, U. (2016). Effective Project Preparation Process: A Key Factor to a Successful PPP Infrastructure Development. International Journal of Engineering Science Invention, 5(8), 1-7. https://doi.org/ https://doi.org/10.23958/ijsei

Nguyen, P. T., Le, Q., Thuy, H., \& Nguyen, T. (2020). Critical Factors Affecting Construction Price Index: An Integrated Fuzzy Logic and Analytical Hierarchy Process. Journal of Asian Finance, Economics and Business, 7(8), 197-204. https://doi.org/10.13106/jafeb.2020.vol7.no8.197

Osei-Kyei, R., \& Chan, A. P. C. (2018). A Best Practice Framework for Public-Private Partnership Implementation for Public Construction Projects in Developing Countries: A case of Ghana. Benchmarking: An International Journal, 25(8), 28062827. https://doi.org/https://doi.org/10.1108/bij-05-2017-0105

Osei-Kyei, R., \& Chan, A. P. C. (2015). Review of studies on the critical success factors for public-private partnership (PPP) projects from 1990 to 2013. International Journal of Project Management, 33(6), 1335-1346. https://doi.org/10.1016/j. ijproman.2015.02.008

Prasad, N. (2007). Privatisation of water: A historical perspective. Law, Environment and Development Journal, 3(2), 217. https:// doi.org/10.2139/ssrn.2323431

Public Relations. (2018). Evaluation of Water Local State Owned Enterprises 2018, The Health Company Is Arising. Retrieved March 1, 2020, from: https://www.pu.go.id/berita/view/16400/ hasil-evaluasi-kinerja-pdam-2018-jumlah-pdam-sehatbertambah

Purbo, R. K., Smith, C., \& Bianchi, R. (2019). Lessons Learned from Public Private Partnerships in Indonesia's Water Sector. Bulletin 
of Indonesian Economic Studies, 55(2), 193-212. Retrieved from https://doi.org/10.1080/00074918.2018.1550250

Putra, A. P. (2018). Public Private Partnership Model on Water Infrastructure Provision Umbulan-East Java from Open Government Context. Airlangga University, Indonesia. https:// doi.org/10.5151/cidi2017-060

Rakić, B., \& Rađenović, T. (2011). Public-Private Partnerships As an Instrument of New Public Management. Economics and Organization, 8(2), 207-220. https://doi.org/https://doi. org/10.22190/

Saaty, T. (2008). Decision making with the analytic hierarchy process. International Journal of Services Sciences, 1(1). https://doi.org/10.1504/IJSSCI.2008.017590

Salim, A., Rustam, A., Haeruddin, H., \& Asriati, A. (2020). Economic Strategy: Correlation between Macro and Microeconomics on Income Inequality in Indonesia. Journal of Asian Finance, Economics and Business, 7(8), 681-693. https://doi.org/10.13106/jafeb.2020.vol7.no8.681

Shi, S., Chong, H. Y., Liu, L., \& Ye, X. (2016). Examining the Interrelationship among Critical Success Factors of Public Private Partnership Infrastructure Projects. Sustainability, 8(12), 1313. https://doi.org/https://doi.org/10.3390/su8121313

UNICEF. (2016). Strategy for Water, Sanitation and Hygiene 20162030. New York, NY: Programme Division UNICEF.
United Nations. (2018). SDG 6 Synthesis Report on Water and Sanitation 2018. Retrieved April 1, 2020, from: https://www. unwater.org/publications/highlights-sdg-6-synthesis-report2018-on-water-and-sanitation-2/

Vo, K. D., Nguyen, P. T., Le, Q., Thuy, H., \& Nguyen, T. (2020). Disputes in Managing Projects : A Case Study of Construction Industry in Vietnam. Journal of Asian Finance, Economics and Business, 7(8), 635-644. https://doi.org/10.13106/jafeb.2020. vol7.no8.635

Wibowo, A., \& Mohamed, S. (2010). Risk criticality and allocation in privatised water supply projects in Indonesia. International Journal of Project Management, 28(5), 504-513. https://doi. org/10.1016/j.ijproman.2009.08.003

Yessentay, A., Kireyeva, A., Khalitova, M., \& Abilkayir, N. (2020). Financing of Healthcare Facilities in Pension System Assets of Ecologically Problematic Regions in Kazakhstan. Journal of Asian Finance, Economics and Business, 7(7), 531-541. https://doi.org/10.13106/jafeb.2020.vol7.no7.531

Zhang, S., Gao, Y., Feng, Z., \& Sun, W. (2015). PPP application in infrastructure development in China : Institutional analysis and implications. International Journal of Project Management, 33(3), 497-509. https://doi.org/https://doi.org/10.1016/j. ijproman.2014.06.006 